\title{
Screening of Different Germplasm against Groundnut Bud Necrosis Virus (GBNV) and Thrips in Tomato
}

\author{
T. Tamilnayagan ${ }^{*}$, M. Suganthy ${ }^{1}$, P. Renukadevi ${ }^{2}$ and V.G. Malathi \\ ${ }^{1}$ Department of Agricultural Entomology, ${ }^{2}$ Department of Plant Pathology, Tamil Nadu \\ Agricultural University, Coimbatore- 641 003, Tamil Nadu, India \\ *Corresponding author
}

\begin{abstract}
Keywords
Germplasm, GBNV, Thrips and Tomato.

Article Info

Accepted:

20 September 2017

Available Online:

10 November 2017 Coimbatore. Totally 25 hybrids/varieties were screened in Rabi season during 2015. None of the varieties/hybrids screened were resistant or immune to GBNV during Rabi season. However, average disease incidence ranged from 7.55 to 25.25 percent indicating moderately resistant to highly susceptible. Tomatoes cultivar namely, PKM-1, PKM-2, PKM-3, VRG-17, VRG-95 and IVRC-1 were found moderately resistant to GBNV recording average disease incidence range is 6.88 to 9.88 and thrips population range from 0-2 per plant. In Sivarna, VRG-89, VRG-155, HAT-20, Co-3, WFM-1, ATL-019, DVR-2, LRC-1, DVRT-2, Yellow fruit, Uttakumari and CE-2004 were found moderately susceptible to GBNV recording average disease incidence range is 10.55 to 13.88 and thrips population range from 2-3 per plant. In CE-12, VRG-90, HN-2, H-24, WFF-1 and CLNR-2 were found susceptible to GBNV recording average disease incidence range is 16.77 to 19.75 and thrips population range from 3-5 per plant were recorded.
\end{abstract}

\section{A B S T R A C T}

The field experiment on screening of tomato lines for GBNV infection was carried out Horticultural College and Research Institute, Tamil Nadu Agricultural University and

\section{Introduction}

Tomato (Lycopersicon esculentum L.) belongs to the genus Lycopersicon under Solanaceae family. It is a native to Peruvian and Mexican region. Tomato is one of the most important "protective foods" because of its special nutritive value. It is one of the most versatile vegetable with wide usage in Indian culinary tradition. Tomatoes are used for soup, salad, pickles, ketchup, puree, sauces and in many other ways. It is also used as a salad vegetable. Tomato has very few competitors in the value addition chain of processing. It is the world's largest vegetable crop after potato and sweet potato, but it tops the list of canned vegetables. Tomato crop is grown in an area of 79900 hectare with the production of 19542 metric tonnes in India (NHB 2016). The major tomato producing states are Bihar, Karnataka, Uttar Pradesh, Orissa, Andhra Pradesh, Maharashtra, Madhya Pradesh, Assam and Tamil Nadu. Tomato is reported to be susceptible to over 40 viruses belonging to Alfamo, Luteo, Carla, Cucumo, Gemini, Poty, Ilar, Nepo, Tombus, Tobamo and Tospovirus groups (Allen and Gibbs, 1990). Among these tomato leaf curl and Tospoviruses are very important. The incidence of Tospoviruses in vegetable crops is increasing year by year and more so in tomato (Krishna Reddy et al., 1997). In the 
world, tomato is known to be naturally infected by four different tospoviruses such as Tomato spotted wilt virus (TSWV), Tomato chlorotic spot virus (TCSC), Groundnut ring spot virus (GRSV) (Heinze et al., 1995). Tomato Tospovirus was reported from Taiwan, which was serologically closely related to Watermelon silver mottle virus (WSMoV) and Peanut bud necrosis virus (PBNV) (Adam et al., 1993).

In India, Tospovirus on tomato was observed for the first time from Niligiris in 1975 and reported as TSWV, later it was reported from Andhra Pradesh (Prasada Rao et al., 1980) Karnataka (Sastry, 1982) Maharashtra (Joi and Summanvar, 1986) and Tamil Nadu (Doraiswamy et al., 1984). The PBNV is widely distributed in India and is one of the most devastating diseases affecting peanut, vegetables like, tomato, chilli, brinjal and pulses, viz., green gram, black gram, soybean and watermelon (Gopal et al., 2010a). Groundnut bud necrosis virus infecting tomato, showed chlorotic, necrotic spots on young leaves and drying of young bud or growing tip followed by necrotic streaks on stem and petioles. Few plants had purple appearance and bronzing of leaves was observed. Early infection in plants resulted yellowing of leaves, stunted growth, finally wilting and death of the plants. Some infected plants set fruits with chlorotic concentric rings with reduced size. Similar type of symptoms was observed by several workers in Karnataka (Hemalatha, 1999, Anjaneya Reddy et al., 2008) and Manjunath, 2008). In India, Groundnut bud necrosis virus (GBNV), Peanut yellow spot virus (PYSV), and Watermelon bud necrosis virus (WBNV) have been reported to infect broad range of vegetables (tomato, potato, chilli, peppers and watermelon) However groundnut bud necrosis virus (GBNV) disease in tomato, a Tospovirus group is causing considerable damage on both crop and yield i $n$ tomatoes. The disease occurs at high proportion in some states especially in Tamil Nadu, Karnataka, Maharashtra and Andhra Pradesh. The losses due to this disease in tomatoes depend mainly on the level of infection, stage of the crop, thrips population and severity of the disease. Early stage of the crop, i.e. 15-20 days after transplanting and flowering stage is highly susceptible for the virus. Considering the importance research study was conducted on screening different germplasm entries against Groundnut Bud Necrosis virus (GBNV) and thrips in tomato.

\section{Materials and Methods}

The field experiment on screening of tomato lines for GBNV infection was carried out Horticultural College and Research Institute, Tamil Nadu Agricultural University and Coimbatore. Totally 25 hybrids and varieties were screened in Rabi season during 2015. Tomato cultivars namely PKM-1, PKM-2, PKM-3, VRG-17, VRG-89, VRG-90, VRG95, VRG-155, IVRC-1, Sivarna, HAT-20, Co-3, WFM-1, ATL-019, DVR-2, DVRT-2, LRC-1, Yellow fruit, Uttakumari, CE-12, CE2004, CLNR-2, HN-2, H-24 and WFF-1. The seeds were sown in nursery beds separately and transplanted in the main field 28 days after sowing with a spacing of $75 \times 60 \mathrm{~cm}$ during Rabi of 2015. The observation on symptom appearance and percent disease incidence was recorded at weekly intervals up to twelve weeks after planting. The following scale (Joi and Summanvar, 1989) was employed for scoring the disease reaction in tomato for TSWV.

To assess the population of thrips in field and observations were made on three leaves per plant, one each from top, middle and bottom region from ten randomly selected plants per farm leaving border rows.

To work out per cent disease incidence (PDI), total number of plants and number of plants infected with GBNV were counted leaving the outs of two rows on all the four sides in 
each farm. PDI was calculated by adopting the following formula (Salam et al., 2010).

Number of infected plants Per cent disease incidence $=$------------- x 100

Total number of plant

\section{Results and Discussion}

In order to evaluate tomato varieties and hybrids for GBNV disease and thrips population screening was carried out under field condition. Totally 25 hybrids /varieties were screened during summer rabi 2015 . The disease reaction was calculated based on the scale employed for scoring disease reaction in varieties and hybrids and expressed as per cent disease incidence of rabi season. The field experiment results revealed that none of the varieties/hybrids screened were resistant or immune to GBNV during Rabi season.
However, average disease incidence ranged from 7.55 to 25.25 percent indicating moderately resistant to highly susceptible. Tomatoes namely, PKM-1, PKM-2, PKM-3, VRG-17, VRG-95 and IVRC-1 were found moderately resistant to GBNV recording average disease incidence range is 6.88 to 9.88 (Table 1) and thrips population range from 0-2 per plant. In Sivarna, VRG-89, VRG-155, HAT-20, Co-3, WFM-1, ATL-019, DVR-2, LRC-1, DVRT-2, Yellow fruit, Uttakumari and CE-2004 were found moderately susceptible to GBNV recording average disease incidence range is 10.55 to 13.88 and thrips population range from 2-3 per plant (Table 1). In CLNR-2, CE-12, VRG-90, HN-2, H-24, WFF-1 and CLNR-2 were found susceptible to GBNV recording average disease incidence range is 16.77 to 19.75 and thrips population range from 3-5 per plant were recorded (Table 1).

Table.1 Screening of tomato cultivar and hybrids for GBNV under field condition

\begin{tabular}{|c|c|c|c|c|c|c|c|c|}
\hline S.No. & $\begin{array}{c}\text { Cultivars/ } \\
\text { Hybrids }\end{array}$ & \multicolumn{6}{|c|}{ Per cent Disease Incidence (PDI) } & $\begin{array}{l}\text { Disease } \\
\text { reaction }\end{array}$ \\
\hline 2 & PKM-2 & 6.12 & 8.02 & 12.33 & 9.55 & 7.88 & 8.78 & MR \\
\hline 4 & VRG-17 & 7.33 & 11.56 & 10.88 & 9.46 & 7.77 & 9.4 & MR \\
\hline 5 & VRG-89 & 10.66 & 12.88 & 17.12 & 15 & 13.33 & 13.79 & MS \\
\hline 6 & VRG-90 & 19.12 & 16.78 & 14.56 & 14.33 & 19.88 & 16.93 & $\mathrm{~S}$ \\
\hline 9 & IVRC-1 & 9.44 & 7.2 & 9.45 & 11.55 & 10.44 & 9.61 & MR \\
\hline 10 & HAT-20 & 11.22 & 14.78 & 12.22 & 13.88 & 12.33 & 12.88 & MS \\
\hline 11 & Co-3 & 14.44 & 11.33 & 13 & 16.33 & 11.33 & 13.28 & MS \\
\hline 12 & WFM-1 & 13.12 & 14.78 & 10.88 & 12.98 & 15.12 & 13.37 & MS \\
\hline 13 & ATL-019 & 11.33 & 16.33 & 15.12 & 11.33 & 12.33 & 13.28 & MS \\
\hline 18 & Uttakumari & 16.12 & 16.78 & 15.78 & 13.78 & 12.12 & 14.91 & MS \\
\hline 19 & CE-2004 & 15.89 & 13.12 & 14.56 & 16.34 & 14.99 & 14.98 & MS \\
\hline 20 & CLNR-2 & 16.99 & 15.99 & 19.56 & 19.98 & 21.67 & 18.83 & $S$ \\
\hline 21 & CE-12 & 19.12 & 16.78 & 14.56 & 14.33 & 19.88 & 16.93 & $\mathrm{~S}$ \\
\hline 22 & $\mathrm{HN}-2$ & 19.9 & 18.78 & 23.56 & 21.12 & 15.78 & 19.82 & $\mathrm{~S}$ \\
\hline 23 & $\mathrm{H}-24$ & 22.14 & 21.11 & 18.34 & 19.55 & 17 & 19.62 & $\mathrm{~S}$ \\
\hline 24 & WFF-1 & 20.12 & 21.78 & 19.56 & 19.15 & 18.23 & 19.76 & $\mathrm{~S}$ \\
\hline 25 & Sivarna & 13.45 & 11.33 & 14.34 & 16.12 & 14.88 & 14.02 & MS \\
\hline
\end{tabular}


Scoring the disease reaction in tomato for TSWV

\begin{tabular}{|c|c|l|l|}
\hline Grade & PDI & Category & Symptoms \\
\hline A & 0.00 & Immune (I) & No symptoms \\
\hline B & 0.1 to 5.00 & Resistant(R) & $\begin{array}{l}\text { Initial symptoms on younger } \\
\text { leaf lets }\end{array}$ \\
\hline C & 5.1 to 10.00 & Moderately Resistant(R) & $\begin{array}{l}\text { Symptoms extended up to } \\
\text { petioles }\end{array}$ \\
\hline D & 10.1 to 15.0 & Moderately susceptible (MS) & $\begin{array}{l}\text { Necrosis of growing branch } \\
\text { including buds }\end{array}$ \\
\hline E & 15.1 to 25.0 & Susceptible (S) & $\begin{array}{l}\text { Necrosis extended up to stem, } \\
\text { covering all plants. }\end{array}$ \\
\hline F & 25.1 and above & Highly susceptible (HS) & Severe necrosis and wilting \\
\hline
\end{tabular}

Anjaneya Reddy et al., (2008) reported that the thirty three varieties/ hybrids of tomato were screened against Tospovirus, none was immune to Tospovirus, two were resistant (1$5 \%$ and ten were found moderately susceptible $\left(\begin{array}{ll}10 & 15 \%\end{array}\right)$. Tomato variety, Marikrit showed moderately resistant and NS2535 had moderately susceptible reaction. Remaining 20 were highly susceptible in the field screening (Manjunath, 2008). Venkata Ramana et al., (2006) screened 63 tomato entries consisting of 20 cultivars, 36 genotypes and 7 wild species in field condition during kharif 2003.The test entries were grouped into six categories based on final per cent PBNV disease incidence at 75 days after transplanting. Only one entry EC 5888 showed a highly resistant reaction, while EC 8630 and EC 26512 were resistant. Pusa uphar, EC 251709, EC 35446, EC 165700, LE 23, IIHR 2187, IIHR 2272, IIHR 2273 and IIHR 2274 were moderately resistant. Lal et al., (2002) screened 48 soybean genotypes in field conditions in three trials of kharif 2001 to identify the resistance against bud blight caused by a strain of ground nut bud necrosis virus. Gopal et al., (2004) reported that the 242 groundnut genotypes screened under field condition, 89/93 -32, ICCV 92269, 83/151-7 and 85/203-06 were found most promising sources of resistance for groundnut bud necrosis virus disease. Jaya Jasmine and
Seemanthini, (1994) observed that none of the varieties screened were fully resistant. However, they showed varied response to the infection. ARTH-4 among the hybrids and CO-3 among the varieties showed less susceptibility while the rest were highly susceptible. $L$. peruvianum appears to be the best resistance source for TSWV, NPH accessions 201 and 374, LA accessions $111372, \quad 385, \quad 4441-1$ and 1113-1, PI accessions 126928, 126930, 126, 944, 126946, 128657, 128600 and 129146 have been found resistant or immune in screening trials (Paterson et al., 1989; Maluf et al., 1991; lizuka et al., 1993 and Krishna Kumar et al., 1993).

Based on the result of the survey it is concluded that the none of the varieties/hybrids screened were resistant or immune to GBNV during rabi season. However, PKM-1, PKM-2, PKM-3, VRG-17, VRG-95 and IVRC-1 were found moderately resistant to GBNV and CLNR-2, CE-12, VRG-90, HN-2, H-24 and WFF-1 were found susceptible to GBNV.

\section{Acknowledgement}

The authors are grateful to Dean, School of Post Graduate Study (SPGS), Director, Professor and Head, Department of 
Entomology, Department of Plant Pathology and Central for Plant Protection Studies and Tamil Nadu Agricultural University for giving assistance during my research period.

\section{References}

Adam, G., S.D. Yeh, D.V.R. Reddy and Green, S.K. 1993.The serological comparison of tospovirus isolates from Taiwan and India with Impatiens necrotic spot virus and different tomato spotted wilt virus isolates. Arch. Virol., 130: 237-250.

Allen, B, and Gibbs, and K.C.1990. Viruses of tropical plants. $\mathrm{CAB}$ International, Oxon, UK. 707pp.

Anjaneya Reddy, B., M. Krishna Reddy, J. Salil, M.S. Patil and Usharani, T.R. 2008. Detection of a tospovirusinfecting tomato (Solanum lycopersicon), Indain J. Virol., 19 (1): 32-35.

Doraiswamy, S., G.A. Ramakrishnan and Jayaraj, R.1984. Studies with a strain of tomato spotted wilt virus. Madras Agric. J., 71: 418-419.

Gopal, K., M. Krsihna Reddy, D.V.R. Reddy and Muniyappa, V. 2010. Transmission of peanut yellow spot virus (PYSV) by Thrips, Scirtothrips dorsalis Hood in groundnut, Arch. Phytopathol. Pl. Prot., 43(5); 421-429.

Gopal, K., R. Jagadeeshwar, G. Prasad Babu and Upadhyay, H.D. 2004, Source of resistance to bud necrosis disease to groundnut. IAN, 24: 36-38.

Heinze, C., E. Maiss, G. Adam and Casper. R. 1995. The complete nucleotide sequence of the $\mathrm{S}$ RNA of a new tospovirus species, representing serogroup IV. Phytopathology, 85: 683690.

Hemalatha. Detection and transmission of tomato necrotic spot tospovirus (TNSV) infecting tomato (Lycopersicon esculentum Mill.) M. Sc (Agri) Thesis Uni. Agric. Sci., Bengaluru, 1999. 81pp lizuka, N., L.S. Bioteux, L.B. Nagata and Dust, A.N. 1993. Sources of resistance to tomato spotted wilt virus in wild Lycopersicon spp. TGC Report, 43: 2022.

Jaya Jasmine, A.P and Seemanthini. R. 1994. Reaction of tomato hybrids to spotted wilt virus. South Indian Hort., 42(1): 55.

Joi, M.B, and Summanwar. A.S. 1986. Occurrence of tomato spotted wilt virus on tomato in Maharashtra J. Hort., 3: 68-72.

Krishna Kumar, N.K., D.E. Ullman and Cho. J.J. 1993. Evaluation of Lycopersicon germplasm for tomato spotted wilt tospovirus resistance by mechanical and thrips transmission. Plant Disease, 77: 938-941.

Krishna Reddy M, R. Usha Rani, K.S. Anil Kumar, K. Madhavi Reddy and Pappu H.R. chlorosis virus Genus Tospovirus infecting Chilli Pepper (Capsicum annum) in India. 2008; Plant Disease. 92(10): 1469.

Lal, S.K., A.I. Bhat, V.K.S. Rana, R.L. Sapna and Anil. K. 2002. Identification of resistant sources against bud-blight disease of soybean (Glycine max (L. Merrill) Indian J. Gen. Pl. Breed., 62(4): 357-358.

Maluf, W.R., M. Toma-Braghini and Corte. R.D.1991. Progress in breeding tomatoes for resistance to tomato spotted wilt. Rev. Bras. Gen., 14: 509525.

Manjunath L. Studies on bud blight disease of tomato caused by groundnut bud necrosis virus, M. Sc. (Agri) Thesis University of Agricultural Science, Dharwad. 2008, pp. 88.

National Horticulture Board 2016. Ministry of Agriculture and Farmers Welfare Government of India. 
Paterson, R.G., S.J. Scott and Gergerich, R.C. 1989. Resistance in two Lycopersicon species to an Arkansas isolated of tomato spotted wilt virus. Euphytica, 43: 173-178.

Prasada Rao, R.D. V.J. Iizuka, N. Ragunatha and Joshi. N.C. 1980. Occurrence of tomato spotted wilt virus on tomato in Andhra Pradesh. Indian Phytopath, 33 (3); 436-439.

Salam S.A., M.S. Patil and Byadgi, A.S. 2011. Status of mungbean yellow mosaic virus disease incidence on green gram. Karnataka Journal of Agricultural Science, 24 (2): 247-248.

Sastry, K.S. 1982. Occurrence of spotted wilt virus on tomato in Karnataka, Curr. Res., 9-10:94.

Venkata Ramana, C., R.D. Prasada Rao V.J. Reddy and P. Venkara Rao and Reddy. Y.N. 2006. Screening of tomato germplasm and wild relatives against peanut bud necrosis virus 34(1): 59-61.

\section{How to cite this article:}

Tamilnayagan, T., M. Suganthy, P. Renukadevi and Malathi, V.G. 2017. Screening of Different Germplasm against Groundnut Bud Necrosis Virus (GBNV) and Thrips in Tomato. Int.J.Curr.Microbiol.App.Sci. 6(11): 2497-2502. doi: https://doi.org/10.20546/ijcmas.2017.611.293 